\title{
Integrated approach to the reconstruction of industrial enterprises
}

\author{
Pavel Oleinik, Nadezhda Cherednichenko ${ }^{1}$, Vitaliy Melnichuk and Anastasiya Bulycheva \\ Moscow State University of Civil Engineering, Yaroslavskoe shosse, 26, Moscow, 129337, Russia
}

\begin{abstract}
The article considers reconstruction as the important direction of fixed assets reproduction. It provides information about industryspecific features of the reconstruction and highlights the most likely works. It also shows the ways to improve the efficiency of reconstruction through the implementation of an integrated approach based on the joint development of solutions by all participants of the reconstruction works. As a result, when developing space-planning and design solutions, organizational and technological solutions are taken into account. The article also concerns the introduction of the most advanced technological processes, the rational use of the facility territory, taking into account the interests of the participants of the reconstruction works. The conditions for the production of reconstruction work are reflected in the real way.
\end{abstract}

\section{Introduction}

Quite often, the reconstruction is accompanied by the expansion of the enterprises by increasing the existing areas or the construction of new workshops and installations.

Fixed assets reproduction is carried out as a result of construction or reconstruction of capital construction projects, as well as their capital repair. Among these areas, the reconstruction of objects occupies a special position due to the need to synchronize it with the update of the manufactured products. In this sense, the general task of reconstruction is to update production in order to bring it in line with the achieved level of scientific and technological progress $[1,2,3]$.

The reconstruction also includes technical re-equipment, which is considered as its variant with a relatively small volume of construction and installation works in the total volume of capital investments. Quite often, the reconstruction is accompanied by the expansion of enterprise facilities by increasing the existing areas or the construction of new workshops and installations $[1,4]$.

\section{Methods}

As practice shows, increasing the effectiveness of the reconstruction of industrial enterprises is directly related to the need for a comprehensive approach to the main stages of

${ }^{1}$ Corresponding author: CherednichenkoND@mgsu.ru 
reconstruction (including design, financing, reconstruction works) and the relationships of elements within each stage.

For example, the peculiarities of reconstruction works determine the specifics of site work execution programme taking into account the modern requirements of the construction industry. At the same time, it is envisaged to improve the structure and content of the elements of site work execution programme by: systematization and in-depth development of organizational and technological documents, typification and unification of organizational and technological solutions, ensuring the completeness of documents and reliability of information for making optimal decisions at all levels of construction management, providing all stages of engineering preparation of construction production with regulatory and instructional documentation, linking design solutions for the production of general construction and special types of work with the main activities of the enterprise, linking spaceplanning and design solutions with the organization and technology of the reconstruction works, more clear linkage of documents of the of site work execution programme $[7,8,9]$.

The composition and content of the site work execution programme are determined by the requirements of state standard SP 48.13330.2011 "Organization of Construction". However, the features of reconstruction and the requirements for their account is not highlighted. At the same time, the site work execution programme is developed after receiving the engineering documentation, which means that organizational and technological solutions are not taken into account in the formation of space-planning and design solutions of the reconstructed objects. Or, since the site work execution programme document is optional, it does not show a clear link between the decisions of the general contractor and subcontractors, and at the same time, the solutions of this document in many cases do not correspond to the real conditions of reconstruction works.

It should be taken into account that the construction, installation and commissioning works during the reconstruction of the workshops of industrial enterprises are mostly carried out in mixed ways, in which one part of the work is performed by contractors, the other part-by commissioning organizations, and the third part - by the industrial enterprise itself.

\section{Results}

A wide variety of industry features (table 1) dictates a wide range of methods of construction and installation works provided by the following: with/without changes in spaceplanning solutions, with/without replacement and strengthening of load-bearing structures, with/without restrictions in the use of mechanization, use of small-scale mechanization only, presence of significant amounts of manual work or large amounts of disassembly work of buildings, structures, constructions; large dispersion of work about the territory of the enterprise.

In this regard, the largest update of production assets can be:

- large reconstruction works at $K_{f} \geq 0.40$

- average reconstruction works at $0.20<K_{f}<0.40$;

- small reconstruction works at $K_{f} \leq 0.20$.

$$
K_{f}=\frac{f}{f_{1}}
$$

where $K_{f}$ - coefficient of production asset renewal

$f$-index of creation of new production assets during reconstruction (thousand rubles)

$f_{1}$-index of productive assets before the reconstruction (thousand rubles)

At the same time, according to the level of external constraint, the territory of the reconstructed enterprise is divided into: 
- extremely space-limited environment $K_{\mathrm{c}}=0$;

- very space-limited environment $0<K_{\mathrm{c}} \leq 0.4$;

- space-limited environment $0.4<K_{\mathrm{c}}<1$;

- environment with space-limit $K_{\mathrm{c}} \geq 1$,

$F_{1}=F-\left(F_{1}^{1}+F_{1}^{2}+F_{1}^{3}+F_{1}^{4}\right)$,

$$
K_{c}=\frac{F_{1}}{F_{2}}
$$

$F_{2}=F_{2}^{1}+F_{2}^{2}+F_{2}^{3}+F_{2}^{4}$,

where $K_{\mathrm{c}}$ - level of external constraint of the territory

$F_{1}$ - free area of the reconstructed enterprise

$F$ - total area of the reconstructed enterprise

$F_{1}^{1}$ - building area of existing buildings and structures

$F_{1}^{2}$ - area of above-ground engineering networks

$F_{1}^{3}$ - area under warehouses and roads

$F_{1}^{4}$ - area of the territory which is in dangerous zones (near flammable liquids, highways, power facilities)

$F_{2}$ - area required to accommodate temporary construction infrastructure

$F_{2}^{1}$ - warehouse space for building structures, products and materials

$F_{2}^{2}$ - area under the household camps

$F_{2}^{3}$ - area of roads and sites required for the period of reconstruction works

$F_{2}^{4}$ - area of construction machinery work areas

In many cases, the reconstruction work includes complex and specific works that require careful study of the technology and increased responsibility for their implementation. Such works include: installation and dismantling of structures and technological equipment, strengthening and replacement of structures, installation of foundations near structures and other foundations, replacement of beams and trusses of coatings in areas difficult to access for installation cranes, increasing the column span without dismantling the coating, laying of communications under roads and buildings without stopping their operation, foundation installation with lowering brackets, installation of bored piles with expansion, installation of protective constructions in the workshops, etc. [10,11, 12].

The named above and other reasons (disunity of developers of design and organizational and technological documentation, weakness of the regulatory framework of the site work execution programme, diversity of many departmental documents, diversity of solutions, etc.) suggest that the importance, validity of decisions and the discipline of the site work execution programme execution should be qualitatively changed, primarily in the direction of increasing the level of industrialization of reconstruction works, technological effectiveness of design solutions and comparability of the estimated and actual cost of work. It is appropriate to note that, except the site work execution programme, there are no other technological regulations in construction production.

The main features of the integrated approach include the joint work of participants of the reconstruction works at all stages in the development of single sustainable solutions.

Table 1. Industrial specifics of reconstruction

\begin{tabular}{|c|c|c|c|c|c|c|}
\hline \multirow[t]{2}{*}{ Industry } & \multicolumn{4}{|c|}{ Production characteristics } & \multirow[b]{2}{*}{$\begin{array}{l}\text { Most likely } \\
\text { works }\end{array}$} & \multirow{2}{*}{$\begin{array}{c}\text { Complex } \\
\text { and } \\
\text { dangerous } \\
\text { works }\end{array}$} \\
\hline & $\begin{array}{c}\text { Technological } \\
\text { process }\end{array}$ & $\begin{array}{l}\text { presence of } \\
\text { aggressive } \\
\text { environment }\end{array}$ & $\begin{array}{c}\text { space- } \\
\text { planning } \\
\text { solutions }\end{array}$ & $\begin{array}{c}\text { nomenclature } \\
\text { of bearing } \\
\text { structures }\end{array}$ & & \\
\hline 1 & 2 & 3 & 4 & 5 & 6 & 7 \\
\hline $\begin{array}{l}\text { Light } \\
\text { industry }\end{array}$ & Continuous & $\begin{array}{l}\text { Dust-forming } \\
\text { materials }\end{array}$ & $\begin{array}{l}\text { Hall, sec- } \\
\text { tional } \\
\text { One-storey } \\
\text { and multi- }\end{array}$ & $\begin{array}{l}\text { Reinforced } \\
\text { concrete } \\
\text { frame, } \\
\text { rarely - brick }\end{array}$ & $\begin{array}{l}\text { Dismantling } \\
\text { and installation } \\
\text { of equipment, } \\
\text { disassembly }\end{array}$ & $\begin{array}{l}\text { Dedusting } \\
\text { of premis- } \\
\text { es to pre- } \\
\text { vent explo }\end{array}$ \\
\hline
\end{tabular}




\begin{tabular}{|c|c|c|c|c|c|c|}
\hline & & & $\begin{array}{l}\text { storey build- } \\
\text { ings } \\
\text { Building } \\
\text { density - } 40 \\
\text { to } 90 \% \text {. }\end{array}$ & \begin{tabular}{|l|} 
walls with \\
metal trusses
\end{tabular} & $\begin{array}{l}\text { and installation } \\
\text { of floors and } \\
\text { partitions, in- } \\
\text { door excavation } \\
\text { and concrete } \\
\text { works, } \\
\text { strengthening } \\
\text { of columns }\end{array}$ & $\begin{array}{l}\text { sion and } \\
\text { remove } \\
\text { fire haz- } \\
\text { ardous } \\
\text { mixtures in } \\
\text { the air }\end{array}$ \\
\hline $\begin{array}{l}\text { Dairy } \\
\text { industry }\end{array}$ & $\begin{array}{l}\text { with } \\
\text { interrupting }\end{array}$ & $\begin{array}{l}\text { Steam, } \\
\text { liquids }\end{array}$ & $\begin{array}{l}\text { Sectional, 1, } \\
2 \text { and 3- } \\
\text { storey build- } \\
\text { ings with a } \\
\text { height of } \\
\text { about } 6 \mathrm{~m}\end{array}$ & $\begin{array}{l}\text { Reinforced } \\
\text { concrete } \\
\text { structures, } \\
\text { panel, brick } \\
\text { walls }\end{array}$ & $\begin{array}{l}\text { Dismantling } \\
\text { and installation } \\
\text { of equipment, } \\
\text { strengthening } \\
\text { of walls, col- } \\
\text { umns and } \\
\text { beams, renova- } \\
\text { tion of floors, } \\
\text { decoration, } \\
\text { redevelopment } \\
\text { of premises }\end{array}$ & $\begin{array}{l}\text { Removal } \\
\text { of } \\
\text { refrigerants } \\
\text { and } \\
\text { coolants }\end{array}$ \\
\hline $\begin{array}{l}\text { Flour- } \\
\text { cereals } \\
\text { and feed } \\
\text { mill } \\
\text { industry }\end{array}$ & Continuous & $\begin{array}{l}\text { Dust-forming } \\
\text { materials }\end{array}$ & $\begin{array}{l}\text { Halls } \\
\text { with/without } \\
\text { division into } \\
\text { sections. } \\
\text { Buildings } \\
\text { have high } \\
\text { floors (up to } \\
40-65 \mathrm{~m} \text { ) }\end{array}$ & $\begin{array}{l}\text { Monolithic } \\
\text { reinforced } \\
\text { concrete } \\
\text { basements, } \\
\text { reinforced } \\
\text { concrete } \\
\text { frame, rein- } \\
\text { forced con- } \\
\text { crete and met- } \\
\text { al bunkers }\end{array}$ & $\begin{array}{l}\text { Dismantling } \\
\text { and installation } \\
\text { of equipment, } \\
\text { disassembly of } \\
\text { walls and foun- } \\
\text { dations for } \\
\text { equipment, } \\
\text { strengthening } \\
\text { of floors, instal- } \\
\text { lation of new } \\
\text { foundations for } \\
\text { equipment }\end{array}$ & $\begin{array}{l}\text { Dedusting } \\
\text { of premis- } \\
\text { es to pre- } \\
\text { vent explo- } \\
\text { sion and } \\
\text { remove } \\
\text { fire haz- } \\
\text { ardous } \\
\text { mixtures in } \\
\text { the air }\end{array}$ \\
\hline $\begin{array}{l}\text { Meat } \\
\text { industry }\end{array}$ & Continuous & $\begin{array}{l}\text { Steam, } \\
\text { smoke, } \\
\text { liquids }\end{array}$ & $\begin{array}{l}\text { Hall, sec- } \\
\text { tional. One- } \\
\text { storey and } \\
\text { multi-storey } \\
\text { buildings. }\end{array}$ & $\begin{array}{l}\text { Reinforced } \\
\text { concrete } \\
\text { frame, light } \\
\text { concrete panel } \\
\text { and brick } \\
\text { walls }\end{array}$ & $\begin{array}{l}\text { Dismantling } \\
\text { and installation } \\
\text { of technologi- } \\
\text { cal equipment, } \\
\text { disassembly of } \\
\text { floors and } \\
\text { walls, construc- } \\
\text { tion of new } \\
\text { buildings, con- } \\
\text { crete work } \\
\text { inside the } \\
\text { premises, rede- } \\
\text { velopment }\end{array}$ & $\begin{array}{l}\text { Removal } \\
\text { of } \\
\text { refrigerants } \\
\text { and } \\
\text { coolants }\end{array}$ \\
\hline
\end{tabular}

Thus, in the preparation of initial data for the design assignment, the joint work of the customer and the general designer with the participation of the general contractor consists in the need to assess the technical level of the main production and the condition of the equipment, assessment of space-planning solutions and the state of the structures of buildings and constructions, preparation of measurement drawings and materials for the inspection of structures, preparation of conclusions on the basis of geological surveys, determination of the scope of work and technical and economic justification of the need for reconstruction works, its duration and priority with the definition of stopping periods (intervals). Materials of the conclusions shall contain results of inspection of the processing equipment, construction designs and, in most cases, justification of methods of production of works with indication of their volumes and ways of dismantle and strengthening of the structures. 
Measuring drawings of structures of buildings and constructions are performed in the absence of technical documentation, as well as when making structural changes and reconstruction of equipment, not included in the technical documentation.

Development of the task for the reconstruction design, carried out by the customer, the general designer and subcontractor design organizations with the participation of the general contractor, includes fundamental decisions on the organization of the reconstruction of existing enterprises, sufficient to justify the accepted technical solutions and evaluation of the duration of reconstruction, taking into account the combination of reconstruction works with the production activities of the enterprise, list of technological redistribution (units), substantiation of reconstruction sequence, sequence and duration of each stage (node), sequence of post-construction of engineering networks and communications, methods of work performance, etc.

Project documentation consists of construction, organizational and technological parts.

The construction part of the project includes basic drawings, design diagrams and working documentation. The contractor is a specialized design organization (Institute) with the participation of the general contractor, which coordinates the technical conditions for the design. The content of this part of the project is: characteristics and justification of spaceplanning and design solutions, methods of dismantling, destruction and strengthening of structures, taking into account the peculiarities of these works (external and internal spacelimits, restrictions on the scale and duration, stopping period duration, methods of work and means of mechanization), technological schemes of strengthening, dismantling and destruction of structures, providing the required stability and geometric immutability of structures and parts of buildings and constructions, schemes of temporary loads on the existing frameworks of buildings and structures, requirements for safety (stability of structures of buildings and constructions during the production of excavation works and strengthening of foundations, dismantling and destruction of structures, safety of works in emergency situations), basic drawings of architectural planning and structural solutions and structural schemes of strengthening of building constructions, mounting openings, schemes of loads on the building frame under the influence of installation mechanisms and building materials. In this case, the basic drawings should take into account all possible methods of work that meet the technology requirements

In addition, the documentation should include: the scheme of fastening mechanisms on building structures, recommendations for the production of unique works and, in the case of the use of alternative production methods of work or new designs, special requirements for security - the restriction of the scope of work, technical characteristics of mechanization, sequence of execution of works and their combination, methods of temporary fixation or reinforcement of structures, diagrams of fences.

Working documentation for reconstruction and technical rearmament of industrial enterprises (in the form of drawings of reinforcement structures) should contain technological equipment, devices and accessories for safe installation and ways to implement the reinforcement structures, the equipment necessary for the use of new non-standard methods of production, recommendations for the production of works taking into account the results of the survey of the structure state, all necessary drawings.

Special requirements for safety measures (identification of possible rutting zones, soil extrusion when foundation is breaking off, etc.) are worked out with the participation of the contractor.

The organizational and technological part of the reconstruction works includes the construction organization project, which is detailed in the site work execution programme.

The executives are specialized design organizations (institutions), as well as operational services of the customer and general contractor. 
The customer determines the reconstruction conditions in the building site organization scheme, which gives a brief description and justification of the main decisions on the organization and technology of reconstruction works, linked to the volume-planning and design solutions, conditions of environment space-limit and the need for material and technical resources.

The main content of the building site organization scheme is the sharing of the enterprise reconstruction into the stages (nodes), composition of works of the preparatory, beforestop, stop and post-stop periods, indicating the volumes and work order, time and duration of stops, conditions for the safe combination of the enterprise activities with the implementation of construction and installation work, the order of site release and engineering communications transfer, organizational and technological schemes for the basic work production (dismantling and reinforcement of structures, dismantling and installation of process equipment, excavation and concrete works), indicating the requirements for design solutions and linking nodes, taking into account the specifics of methods of production and accepted means of mechanization, detailed construction plans, the order of delivery of equipment, structures and materials, sets of mechanization tools, including operating equipment and machinery, assignments for the development of protective equipment, fences, supporting and unloading devices, non-standard rigging, equipment and padding tools.

The main content of the project of work production: detailed general construction plans for all periods of reconstruction works, clarified organizational and technological solutions (technological maps of the work production), calendar schedules; working drawings of nonstandard equipment, tools and accessories [3, 13, 14].

The implementation of the integrated approach to the reconstruction also requires the appropriate coordination of the participants of the investment process: the senior management staff of the reconstructed enterprise - the customer, the general design and general contracting organizations, suppliers of equipment, construction industry enterprises and other organizations.

The general designer makes schedules for issuing design estimates for organizational and technological solutions.

The general contractor prepares the characteristics of construction organizations, including the annual volume of construction and assembly work, the structure and equipment with means of mechanization, transport, personnel, technical and economic performance indicators, develops normative and instructive documentation, determines the level of technical readiness of the reconstruction object $[7,15]$.

The subcontractors represent diagrams of works, as well as the enterprises of the construction industry represent the supply schedule of structures and components.

The schedules of reconstruction works are based on the calculation of the intensity of the leading process (dismantling and installation of structures) and its duration, as well as on the work stage (node) sequence. The duration of work is determined by the number of workers and their productivity. In the absence of the necessary norms for determining the output in the conditions of reconstruction works, the norms for new construction should be applied, taking into account specific conditions.

\section{Conclusion}

Reconstruction is the most important direction of fixed asset reproduction and its effectiveness depends on the coordinated work of the participants at all stages of design, preparation and production of works, as well as financing. At the same time, for example, spaceplanning and structural solutions practically do not take into account organizational and technological solutions, and the project of works becomes an optional execution document. 
It is advisable in the reconstruction of industrial enterprises to implement an integrated approach in which the managing staff of the enterprise (customer), the general designer and the general contractor jointly prepare the initial data for the design assignment, develop such a task, determine the main solutions, including solutions in the projects of construction and projects of works. At the same time, the main participants of the reconstruction works, if necessary, involved other participants (subcontractors, equipment suppliers, etc.) in the development of rational solutions.

This work was financially supported by Ministry of Science and Higher Education of the Russian Federation (\#NSh-3492.2018.8).

\section{References}

1. Oleinik P.P., Kuzmina T.K., The choice of rational solutions for the reconstruction of textile industry enterprises. Proceedings of Higher Educational Institutions. Technology of textile industry, 3 (369), 11-16 (2017)

2. Arakelyan G.G., Oleinik P.P., Efficient technology of reconstruction of dilapidated buildings. Industrial and Civil Engineering, 9, 36 (2009)

3. Kuzmina T.K., Cherednichenko N., Systematization of the Major Stages of the Client in Certain Branches of Construction Production / MATEC Web Conf., 86, 05012 (2016)

4. Oleinik P.P., Brodsky V.I., Features of the organization of construction in the reconstruction of buildings and structures. Technology and Organization of Construction Production, 4 (5), 40-45 (2013)

5. Kuzmina T.K., Adaptation of technical customer activity in market conditions. $\mathrm{PhD}$ thesis: 05.23.08. Moscow State University of Civil Engineering. Moscow (2012)

6. Shirshikov B.F., Ershov M.N. Reconstruction of facilities. Organization of work, restrictions, risks. Moscow. Library of scientific developments and projects of MGSU (2010)

7. Azariy L. Integral Potential Effectiveness of Organizational-Technological and Managerial Decisions of Building Object. Applied Mechanics and Materials, 584-586, 22302232 (2014)

8. Oleinik P.P., Brodsky V.I., Preparation of construction production in construction and reconstruction of industrial enterprises. MGSU Bulletin, 1-2, 248-252 (2011)

9. Nikiforov A., Meneylyuk I., Ershov M. Optimization of Engineering Structure Reconstruction on the Organizational and Technological Constraints. Bulletin of the Kharkiv National Automobile and Highway University, 72, 151-156 (2016)

10. Oleinik P.P., Brodsky V.I., Technical regulation of organization safety in construction. Technology and Organization of Construction Production, 1, 27-32 (2014)

11. Oleinik P.P., Brodsky V.I., Grigorieva L.S. Determining the Degree of Mobility of Building Systems. Applied Mechanics and Materials, 580-583, 2253-2256 (2014)

12. Lapidus A.A., Makarov A.N. Fuzzy Sets on Step of Planning of Experiment for Organization and Management of Construction Process. MATEC Web of Conf., 05003 (2016)

13. Oleinik P.P., Sinenko S., Zhadanovsky B., Brodsky V., Kuzhin M. Construction of a complex object. MATEC Web of Conf., IPICSE 04059 (2016)

14. Oleinik P.P., Kuzmina T.K., Zenov V. Intensification of the Investment Process of Construction. MATEC Web of Conf. 86, 05019 (2016)

15. Yershov M.N., Ishin A.V., Oleynik P.P., Lapidus A.A., Telychenko V.I., Tumanov D.K., Feldman O.A. Technological and organizational aspects of reconstruction of buildings. Technology and Organization of Construction Production, 3 (8), 10-17 (2014) 